\title{
Ichthyofauna of streams from the lower Iguaçu River basin, Paraná State, Brazil
}

\author{
Crislei Larentis $^{1,5}$, Rosilene Luciana Delariva ${ }^{1}$, Louise Cristina Gomes ${ }^{1}$, Dirceu Baumgartner ${ }^{2}$, \\ Igor Paiva Ramos ${ }^{3}$ \& Diesse Aparecida de Oliveira Sereia ${ }^{4}$ \\ ${ }^{1}$ Universidade Estadual do Oeste do Paraná, Pós-Graduação em Conservação e Manejo de Recursos Naturais, \\ Cascavel, Paraná, Brazil \\ ${ }^{2}$ Universidade Estadual do Oeste do Paraná, Centro de Engenharias e Ciências Exatas, Cascavel, \\ Paraná, Brazil \\ ${ }^{3}$ Universidade Estadual Paulista, Faculdade de Engenharia, Departamento de Biologia e Zootecnia, \\ Ilha Solteira, São Paulo, Brazil \\ ${ }^{4}$ Universidade Tecnológica Federal do Paraná, Centro de Ciências Biológicas, Dois Vozinhos, Paraná, Brazil \\ ${ }^{5}$ Corresponding author: Crislei Larentis,e-mail: crislei.larentis@hotmail.com
}

LARENTIS, C., DELARIVA, R.L., GOMES, L.C., BAUMGARTNER, D., RAMOS, I.P., SEREIA, D.A.O. Ichthyofauna of streams from the lower Iguaçu River basin, Paraná State, Brazil. Biota Neotropica. 16(3): e20150117. http://dx.doi.org/10.1590/1676-0611-BN-2015-0117

\begin{abstract}
The drainages of the Iguaçu River basin, as well as the main channel of the river, have peculiar characteristics resulting from geomorphological processes in this area, including the formation of the Iguaçu River Falls. This slope in the lower portion of the basin is a biogeographical barrier to many organisms. In this study was inventoried the fish fauna of streams of the lower Iguaçu River basin, evaluating possible differences in the species composition upstream and downstream of this biogeographical barrier. Sampling were conducted between 2004 and 2013, in five streams, three upstream and two downstream of the Iguaçu River Falls, using electrofishing. The nMDS analysis was run to investigate possible groupings of similar fauna between the streams sampled. The scores of this test were tested as to the significance of groupings with the Hotelling $\mathrm{T}^{2}$ test. The indicator value method (IndVal) was used to detect the distribution of species among the groups of the streams upstream and downstream of the Iguaçu River Falls. We collected 18,908 individuals of six orders, 11 families, and 40 species. Siluriformes and Characiformes had the highest species richness; Cyprinodontiformes presented the highest abundance. Considering the species recorded, 21 are considered natives to the Iguaçu River basin, including 15 endemic, wich were found only in streams upstream of the falls. Additional 18 species were verified only in the streams downstream of such barrier. Four species were common to both stretches. The axis 1 of the nMDS separated two groups: streams upstream (S1, S2 and S3) and streams downstream of the Iguaçu River Falls (S4 and S5). The indicator species analysis also indicated a distinction between the groups of streams, that were significantly different (Hotelling's $\mathrm{T}^{2}=234.36, \mathrm{p}<0.0001$ ). The number of endemic species in the streams upstream of the Falls (15 spp.) evidences a significant effect of isolation promoted by the Iguaçu River Falls, and confirms the role of this barrier in the vicariant processes and endemism typical of this basin. These results emphasize the importance of conserving these ecosystems, once the extinction of species in this region means the irreversible loss of them. Keywords: Biogeographic barrier, endemics species, fish.
\end{abstract}

LARENTIS, C., DELARIVA, R.L., GOMES, L.C., BAUMGARTNER, D., RAMOS, I.P., SEREIA, D.A.O. Ictiofauna de riachos da bacia do baixo rio Iguaçu, estado do Paraná, Brasil. Biota Neotropica. 16(3): e20150117. http://dx.doi.org/10.1590/1676-0611-BN-2015-0117

Resumo: As drenagens da bacia do rio Iguaçu, bem como o canal principal do rio, possuem características peculiares resultantes de processos geomorfológicos dessa área, incluindo a formação das Cataratas do rio Iguaçu. Esse desnível na porção inferior da bacia constitui uma barreira biogeográfica para muitos organismos. Neste trabalho inventariamos a fauna de peixes de riachos na porção do baixo rio Iguaçu, avaliando possíveis diferenças na composição de espécies acima e abaixo dessa barreira biogeográfica. Entre 2004 e 2013, foram amostrados cinco riachos, sendo três localizados acima das Cataratas do Iguaçu e dois abaixo, por meio de pesca elétrica. Para investigar possíveis padrões de agrupamentos de fauna similares entre os riachos amostrados foi 
realizada uma análise nMDS, cujos escores foram testados quanto à significância dos agrupamentos utilizando o teste de $\mathrm{T}^{2}$ de Hotelling. O valor indicador (IndVal) foi usado para detectar a distribuição das espécies entre os grupos de riachos. Foram amostrados 18.908 indivíduos, pertencentes a seis ordens, 11 famílias e 40 espécies. As ordens Siluriformes e Characiformes destacaram-se em riqueza de espécies; Cyprinodontiformes apresentou maior abundância. Do total de espécies amostradas, 21 são consideradas nativas da bacia do rio Iguaçu, sendo 15 delas endêmicas e registradas somente nos riachos acima das Cataratas do rio Iguaçu. Outras 18 espécies foram registradas somente nos riachos que desembocam abaixo das cataratas. Quatro espécies foram comuns em ambos os ambientes. A dimensão do eixo 1 da análise nMDS resultou na separação de dois grupos: riachos acima (S1, S2 e S3) e riachos abaixo das cataratas (S4 e S5). A análise de espécies indicadoras também indicou a distinção entre os grupos de riachos, sendo que esses agrupamentos foram significativamente diferentes (Hotelling's $\mathrm{T}^{2}=234.36$, $\mathrm{p}<0.0001)$. O número de espécies endêmicas registrado nos riachos acima das cataratas (15 spp.), demonstra um significativo efeito de isolamento da fauna proporcionado pelas Cataratas do rio Iguaçu e confirmam o papel dessa barreira nos processos vicariantes e endemismos característicos dessa bacia. Esses resultados ressaltam a importância da preservação desses ecossistemas, pois a extinção de espécies nessa região significa a perda global dessas entidades biológicas.

Palavras-chave: Barreira biogeográfica, espécies endêmicas, peixes.

\section{Introduction}

The Paraná State, Southern Brazil, has 16 basins (Parolin et al. 2010), including the Iguaçu River basin, formed by the longest river in the Paraná State with approximately 1,080 km (Garavello et al. 2012). The formation of its basin dates back to the Mesozoic era and the beginning of the Paleozoic and was associated with staggered movements of uplift of the Serra do Mar (Parolin et al. 2010). Considering the confluence of the Atuba and Iraí rivers as its origin, the Iguaçu River runs in the east-west direction from its headwaters in the Serra do Mar to its mouth on the Paraná River (Baumgartner et al. 2012). Along its course, it crosses different geological and geomorphological units, with an altitude range of $830 \mathrm{~m}$, considered as a typical plateau river, with numerous rapids and falls. Among these, stands out the Iguaçu River Falls with 82 meters, in addition to other hundreds of waterfalls in the basin, which result from the geological structure caused by basaltic spills. The Iguaçu River and its tributaries features a fauna of small-sized fish, with a high degree of endemism (Vicari et al. 2006), possibly due to the geographical isolation given by the Iguaçu River Falls that isolated this river from the lower Paraná River basin (Baumgartner et al. 2012).

Biogeographical barriers are a key factor in the composition of regional faunas and especially in promoting endemism (Rahel 2007). Besides, the presence of barriers, such as waterfalls, promotes geographical isolation of habitats that increase the speciation rate in these isolated environments (Cracraft 1982), mainly by limiting gene flow, and promoting the diversification of species (Meeuwig et al. 2010). These barriers determine the degree of connectivity of water bodies within the basin, directing the speciation process by influencing the availability of habitats for aquatic species (Dias et al. 2012).

The geological event that formed the Iguaçu River Falls back to the Cretaceous period 130 million years ago (Parolin et al. 2010), which has possibly generated a cladogenic event for most fish species of the Iguaçu River. According to Rahel (2007), the Iguaçu River Falls are classified as a barrier level three for the movement of fish, that is, they promote the isolation of the fish fauna within a basin, ensuring that these species do not colonize other regions unless by human intervention.
In the Iguaçu River basin, $75 \%$ of fish species are endemic (Zawadzki et al. 1999), but this fauna has undergone changes mainly caused by human activities (Baumgartner et al. 2006). Rapid population growth leads to urban sprawl and expansion of agriculture increasingly closer to freshwater environments, affecting negatively the physical and biological structure of these environments (Cunico et al. 2006, Pereira et al. 2014). In this way, besides the threat that human activities cause, there are few studies on streams in the Paraná State (Pavanelli \& Caramaschi 2003, Cunico et al. 2006, 2009, Galves et al. 2007, Araujo et al. 2011, Daga et al. 2012, Delariva \& Silva 2013). In the Iguaçu River basin, stand out the studies conducted in the upper reach of the basin (Suzuki et al. 1997, Vitule \& Abilhoa 2003) and surveys of species in streams of the lower Iguaçu River (Suzuki et al. 1997, Bifi et al. 2006, Baumgartner et al. 2012).

Most rivers and streams forming the Iguaçu River basin are located upstream of the Iguaçu River Falls, but some streams have connection downstream of this barrier, which is located about $18 \mathrm{~km}$ upstream of the mouth of the Iguaçu River into the lower Paraná River basin. Although belonging to the Iguaçu River basin, these streams may have been affected by the same cladogenic event and hold a fish fauna similar to that observed for the Paraná River basin. In this sense, aiming to investigate the fish fauna composition of streams upstream and downstream of the Iguaçu River Falls, this study surveyed the fish fauna in first- and second-order streams of the lower Iguaçu River basin. Thus, this study provides a list of species, showing the occurrence and expansion of distribution and identified possible dissimilarities between the fish faunas located in these sections (up- and downstream of the falls).

\section{Material and Methods}

\section{Study Area}

The Iguaçu River basin encompasses an area of $55,108.04 \mathrm{~km}^{2}$ in the Paraná State, covering 116 municipalities (Parolin et al. 2010) and is subdivided into three hydrographical units: upper, middle, and lower Iguaçu River. In the lower stretch is located the Iguaçu River Falls, in 
the municipality of Foz do Iguaçu, PR, considered the largest falls in volume of water on the planet, which fall through a deep crevice, with an gap of 72 meters and an average volume of $1.551 \mathrm{~m}^{3} / \mathrm{second}$ (SEMA 2013). On the Brazilian side of the Iguaçu River Falls and vicinity of the Iguaçu River in this region, is situated the Iguaçu National Park, a conservation unit essential for the country's biodiversity, because it protects the Iguaçu River Falls and constitutes the largest remnant area of preservation of semideciduous forest of the Paraná State. In the lower Iguaçu River region, the main economic activity is agriculture, especially the cultivation of soybeans and corn, and pastures, which was the prevailing scenario in the vicinity of the streams sampled.

The basins of the studied streams drain, directly or indirectly, into the Iguaçu River, however, flow into upstream (S1, S2, S3) and downstream (S4 and S5) of the Iguaçu River Falls (Figure 1). So, they are separated and susceptible to geographic isolation generated by this natural barrier.

\section{Fish sampling}

The sampling of the fish fauna was performed between 2004 and 2013 in five streams, totaling 11 sampling sites. Samplings were conducted in different periods: Padres River (S1) - quarterly at two sites, between July 2004 and December 2005, with two samplings in 2006 (March and May); Cascavel River (S2) - quarterly samples at two sites between August 2011 and February 2012; Jumelo Stream (S3) - an unique site on the headwaters in September and November 2011, March and July 2012 and July 2013; Poço Preto Stream (S4) and Arroio Dourado Stream (S5) - sampled at three sites every four months between May 2010 and April 2011. The main physical characteristics and geographical coordinates are shown in Table 1. Fish were collected by electrofishing technique with three paces of 40 minute in 50 meters length at each reach. The electrofishing equipment was powered by a portable generator (Honda, $2.5 \mathrm{~kW}, 220 \mathrm{~V}, 3-4 \mathrm{~A}$ ) connected to a DC transformer, with two electrified net rings (anode and cathode). Output voltage varied from 400 to $600 \mathrm{~V}$, and we installed blocking nets (mesh size $5 \mathrm{~mm}$ ) at the ends of each reach to prevent the escape of fish. After sampling, specimens were sacrificed in a solution of clove oil (Eugenol, 2 drops per liter; $c f$. American Veterinary Medical Association 2001), and fixed in $10 \%$ formalin and then preserved in $70 \%$ alcohol.

Specimens were identified according to Baumgartner et al. (2012), Garavello et al. (2012), Garavello \& Sampaio (2010), and Graça \& Pavanelli (2007). Voucher specimens were deposited at the fish collection of Nupélia (Núcleo de Pesquisas em Limnologia, Ictiologia
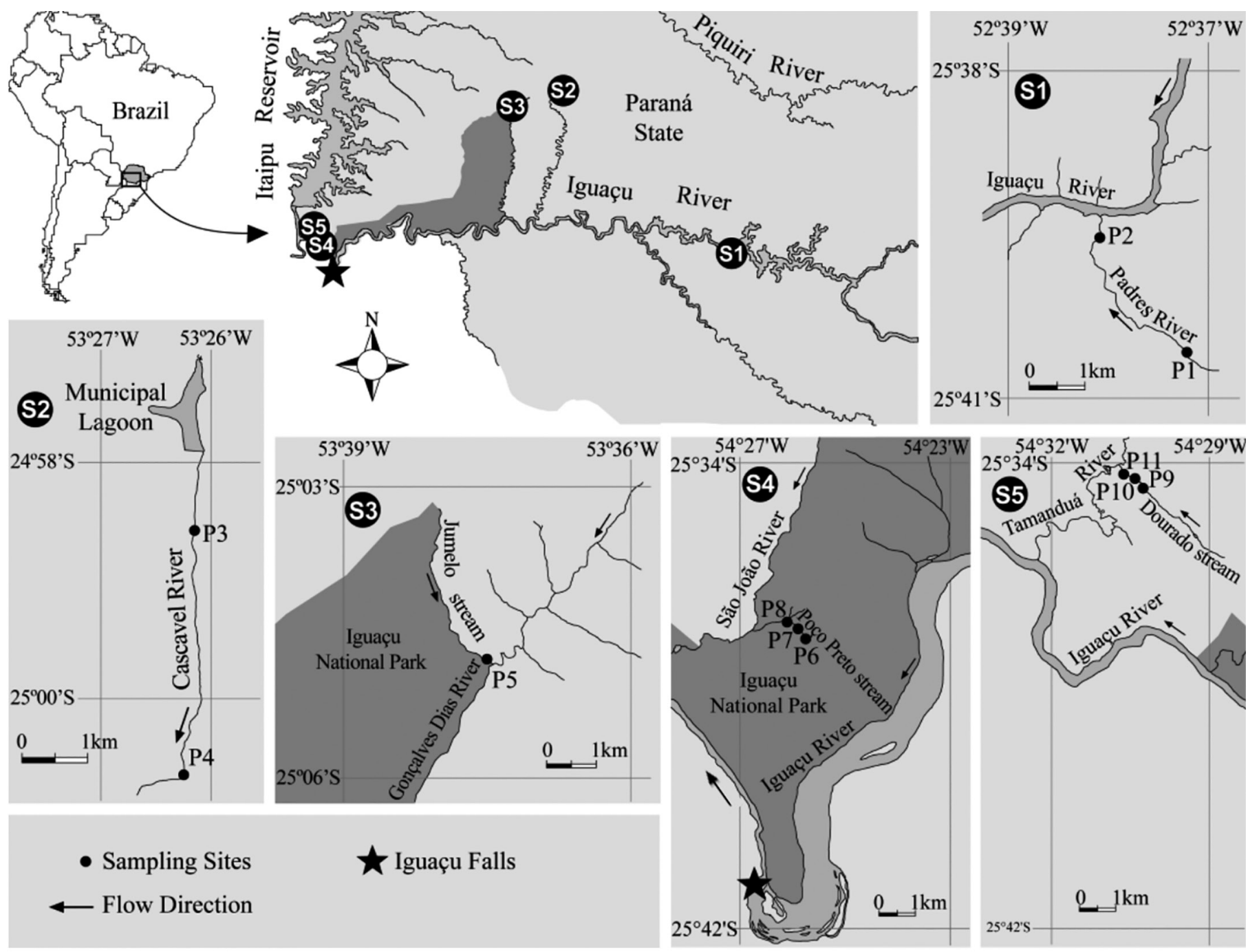

Figure 1. Streams studied in the lower Iguaçu River basin, Paraná State, Brazil. 
Larentis, C. et al.

Table 1. Physical characteristics of the sampled sites in Iguaçu River basin, Paraná State. Brazil. S1, S2 until S5 = Stream’s number. P1, P2, P3 until P11 = sampled portions.

\begin{tabular}{|c|c|c|c|c|c|c|c|}
\hline SITES & COORDINATES & WIDTH (m) & DEPTH (m) & $\begin{array}{l}\text { PREDOMINANT } \\
\text { SUBSTRATE }\end{array}$ & $\begin{array}{l}\text { RIPARIAN } \\
\text { VEGETATION }\end{array}$ & $\begin{array}{l}\text { PHYSIOGRAPHY } \\
\text { CHANNEL }\end{array}$ & OBSERVATIONS \\
\hline $\begin{array}{l}\text { Padres } \\
\text { River (S1) }\end{array}$ & $\begin{array}{l}\mathrm{P} 1-25^{\circ} 40^{\prime} 34.81^{\prime \prime S} \\
52^{\circ} 37^{\prime} 6.05^{\prime \prime} \mathrm{W} \\
\mathrm{P} 2-25^{\circ} 39^{\prime} 34.777^{\prime \prime} \mathrm{S} \\
52^{\circ} 38^{\prime} 2.514^{\prime \prime} \mathrm{W}\end{array}$ & $\begin{array}{l}\mathrm{P} 1-2.00-4.10 \\
\mathrm{P} 2-2.00-4.10\end{array}$ & $\begin{array}{l}\text { P1-0.10-0.28 } \\
\text { P2-0.10-0.55 }\end{array}$ & $\begin{array}{l}\text { Muddy alternated } \\
\text { with argil in the } \\
\text { lower stretch, } \\
\text { rubble in the upper } \\
\text { stretch, and small } \\
\text { amount of shelters. }\end{array}$ & $\begin{array}{l}\text { Variables ranges } \\
\text { of trees and } \\
\text { shrubs }\end{array}$ & $\begin{array}{l}\text { Low-speed stream } \\
\text { in both of the } \\
\text { points. }\end{array}$ & $\begin{array}{l}\text { Wide range of } \\
\text { soil devoid of } \\
\text { vegetation, because } \\
\text { is within of rural } \\
\text { areas. }\end{array}$ \\
\hline $\begin{array}{l}\text { Cascavel } \\
\text { River (S2) }\end{array}$ & $\begin{array}{l}\mathrm{P} 3-24^{\circ} 58^{\prime} 33.57^{\prime \prime} \mathrm{S} \\
53^{\circ} 26^{\prime} 6.41^{\prime \prime} \mathrm{W} \\
\mathrm{P} 4-25^{\circ} 0^{\prime} 32.10^{\prime \prime S} \mathrm{~S} \\
53^{\circ} 26^{\prime} 11.10^{\prime \prime} \mathrm{W}\end{array}$ & $\begin{array}{l}\text { P3-1.00-2.50 } \\
\text { P4-1.00-3.00 }\end{array}$ & $\begin{array}{l}\text { P3-0.30-0.60 } \\
\text { P4-0.40-0.70 }\end{array}$ & $\begin{array}{l}\text { Rubble } \\
\text { predominant in } \\
\text { both of the points. }\end{array}$ & $\begin{array}{l}\text { P3- present } \\
\text { in only one } \\
\text { of the edges; } \\
\text { P4- present in } \\
\text { both of the banks }\end{array}$ & $\begin{array}{l}\text { Low-speed stream } \\
\text { in all of the sites } \\
\text { sampled. }\end{array}$ & $\begin{array}{l}\text { The sites sampled } \\
\text { are within of the } \\
\text { urban areas. }\end{array}$ \\
\hline $\begin{array}{l}\text { Jumelo (S3) } \\
\text { (headwater } \\
\text { stretch) }\end{array}$ & $\begin{array}{l}\mathrm{P} 5-25^{\circ} 04^{\prime} 46.62^{\prime \prime} \mathrm{S} \\
53^{\circ} 37^{\prime} 26.42^{\prime \prime} \mathrm{W}\end{array}$ & P5-2.00-4.00 & P5-0.20-1.00 & $\begin{array}{l}\text { Rocky, rubble, } \\
\text { pebble and silt. }\end{array}$ & $\begin{array}{l}\text { Right bank } \\
\text { with Riparian } \\
\text { vegetation } \\
\text { preserved. Left } \\
\text { bank with range } \\
\text { of trees and } \\
\text { shrubs between } 5 \\
\text { and } 10 \mathrm{~m} \text {. }\end{array}$ & $\begin{array}{l}\text { Rapids with mean } \\
\text { depth of } 0.30 \mathrm{~m} \text {, } \\
\text { and pools of up to } \\
1.00 \mathrm{~m} \text { in depth. }\end{array}$ & $\begin{array}{l}\text { The right bank } \\
\text { belongs to } \\
\text { Iguaçu National } \\
\text { Park, a area of } \\
\text { preservation. The } \\
\text { left bank is within } \\
\text { of rural areas. }\end{array}$ \\
\hline Poço Preto (S4) & $\begin{array}{l}\mathrm{P} 6-25^{\circ} 36^{\prime} 48.04 ” \mathrm{~S} \\
54^{\circ} 25^{\prime} 54.099^{\prime \prime} \mathrm{W} \\
\mathrm{P} 7-25^{\circ} 37^{\prime} 19.3 ” \mathrm{~S} \\
54^{\circ} 26^{\prime} 52.66^{\prime} \mathrm{W} \\
\mathrm{P} 8-25^{\circ} 37^{\prime} 40.5^{\prime \prime S} \mathrm{~S} \\
54^{\circ} 26^{\prime} 53^{\prime \prime} \mathrm{W}\end{array}$ & $\begin{array}{l}\text { P6-1.00 -1.89 } \\
\text { P7-1.60-2.88 } \\
\text { P8-2.70-3.41 }\end{array}$ & $\begin{array}{l}\text { P6-0.20-0.49 } \\
\text { P7-0.55-0.90 } \\
\text { P8-2.30-2.95 }\end{array}$ & $\begin{array}{l}\text { Partially rocky } \\
\text { substrate with } \\
\text { different grain } \\
\text { textures. }\end{array}$ & $\begin{array}{l}\text { Riparian } \\
\text { vegetation on } \\
\text { both banks } \\
\text { composed } \\
\text { of pionners } \\
\text { formations of } \\
\text { rainforest river } \\
\text { influence. }\end{array}$ & $\begin{array}{l}\text { Predominance of } \\
\text { rapids. }\end{array}$ & $\begin{array}{l}\text { Located inside } \\
\text { of a area of } \\
\text { preservation } \\
\text { (Iguaçu National } \\
\text { Park). }\end{array}$ \\
\hline $\begin{array}{l}\text { Arroio Dourado } \\
\text { (S5) }\end{array}$ & 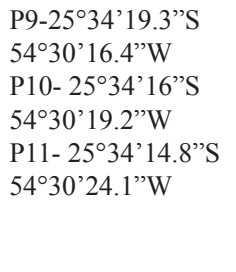 & $\begin{array}{l}\text { P9-1.80-2.24 } \\
\text { P10- 2.00- } 2.96 \\
\text { P11- 2.50- } 3.10\end{array}$ & $\begin{array}{l}\text { P9-0.10-0.29 } \\
\text { P10- } 0.22-0.39 \\
\text { P11- 0.10- } 0.15\end{array}$ & $\begin{array}{l}\text { Partially rocky } \\
\text { substrate with } \\
\text { different grain } \\
\text { textures. }\end{array}$ & $\begin{array}{l}\text { Riparian } \\
\text { vegetation on } \\
\text { both banks } \\
\text { composed } \\
\text { of pionners } \\
\text { formations of } \\
\text { rainforest river } \\
\text { influence. }\end{array}$ & $\begin{array}{l}\text { Predominance of } \\
\text { rapids. }\end{array}$ & $\begin{array}{l}\text { Soil around mainly } \\
\text { occupied by } \\
\text { pastures. }\end{array}$ \\
\hline
\end{tabular}

e Aquicultura), Universidade Estadual de Maringá- UEM, and at the fish collection of Gerpel (Grupo de Pesquisas em Recursos Pesqueiros e Limnologia) - Universidade Estadual do Oeste do Paraná - UNIOESTE.

\section{Data Analysis}

To identify possible groupings of similar fauna between streams, we applied a non-metric multidimensional scaling analysis (nMDS) to summarize the composition of fish assemblages using the Jaccard distance and following the general nMDS procedure proposed by McCune \& Grace (2002). We obtained a confidence index (Stress), which determines the degree of proximity of the graphical representation to the real data. Stress values below 0.20 allow potential two-dimensional (2D) use of the nMDS. Data were randomized 100 times, and the stability criterion was 0.005 standard deviations in the stress after 200 iterations. This analysis was carried out using the numerical abundance matrix of each sampling site and month.

To test the null hypothesis of no difference in composition of the fish assemblage between sites upstream and downstream of the falls summarized by the nMDS, we used a multivariate pairwise comparisons between two groups (upstream and downstream of the falls), using the Hotelling $\mathrm{T}^{2}$ test. This analysis indicates whether a multidimensional sample belongs to a particular multidimensional group. As closer sites have a higher chance to be similar, we applied a Euclidean distance on UTM (site coordinates), obtaining proportional geographic distances between them. We used a Mantel's test on the distances between fish assemblage abundances matrix (nMDS) and geographic distances matrix with the objective of controlling possible geographical effects. Both results were reported based on 10.000 permutations.

The indicator value method (IndVal; Dufrêne \& Legendre 1997) was used to detect how differently each species is distributed among the groups of the streams upstream and downstream of the Iguaçu River Falls. The indicator value of a species varies from 0 to 100, and it reaches its maximum value when all individuals of a species occur in all sites within a single nMDS group.

All analyses were run in the software Past (Hammer et al. 2001), except the indicator value method, performed in the PCOrd ${ }^{\circledR} 6.0$ (McCune \& Mefford 2011).

\section{Results}

In total, we collected 18,908 individuals belonging to six orders, 11 families, and 40 species (Table 2). Siluriformes was the most representative with $50 \%$ of the species richness, followed by Characiformes (31\%). As to numerical abundance, the most 
representative was Cyprinodontiformes (64\%), followed by Characiformes $(23 \%)$ and Siluriformes $(11 \%)$. Characidae and Loricariidae were the highest in number of species $(22 \%$ each). The largest-sized species was Synbranchus cf. marmoratus Bloch, 1795 (53.7 cm total length), and the smallest specimen was Phalloceros harpagos Lucinda, 2008, with standard length (SL) of $0.6 \mathrm{~cm}$.
Among the species sampled, 12 are possibly not described, already that they presented morphological characters different from their congeners currently described for the region. In such cases, Characidium sp. 2, Trichomycterus sp. 1, Trichomycterus sp. 2, and Ancistrus sp. were sensu Baumgartner et al. (2012), and Characidium sp. 1 was sensu Graça \& Pavanelli (2007). Regarding the origin of the species, 21 were native

Table 2. List of fish species and their respective abundances at sampling stations in Iguaçu River basin. Systematic positions were based on Nelson (2006) to all orders, and Siluriformes families; Reis et al. (2003) to others families, except Characidae that follow Mirande (2009). The column "Origin" refers to species classified in native $(\mathrm{N})$ and non-native $(\mathrm{NN})$ to the of lower Paraná River and Iguaçu River basins. $\mathrm{S}=$ sites of sampling. NUP - vouchers specimens deposited in Fish Collection of Núcleo de Pesquisas em Limnologia, Ictiologia e Aquicultura - Nupélia; and CIG - vouchers specimens deposited in Fish Collection of Grupo de Pesquisas em Recursos Pesqueiros e Limnologia - Gerpel.

\begin{tabular}{|c|c|c|c|c|c|c|c|c|c|c|}
\hline \multirow[b]{2}{*}{ Taxon } & \multirow[b]{2}{*}{ Common name } & \multicolumn{8}{|c|}{ Origin } & \multirow[b]{2}{*}{$\begin{array}{l}\text { Voucher } \\
\text { specimens }\end{array}$} \\
\hline & & $\begin{array}{c}\text { Lower } \\
\text { Paraná } \\
\text { River }\end{array}$ & $\begin{array}{l}\text { Iguaçu } \\
\text { River }\end{array}$ & S1 & S2 & S3 & S4 & S5 & Total & \\
\hline \multicolumn{11}{|l|}{ CHARACIFORMES } \\
\hline \multicolumn{11}{|l|}{ Crenuchidae } \\
\hline Characidium sp. 1 & & $\mathrm{~N}$ & $\mathrm{NN}$ & & & & $\mathrm{x}$ & $\mathrm{x}$ & 42 & $\begin{array}{l}\text { CIG 1410, CIG } \\
1422\end{array}$ \\
\hline \multicolumn{11}{|l|}{ Characidae } \\
\hline Astyanax sp. 1 & & $\mathrm{~N}$ & $\mathrm{NN}$ & & & & $\mathrm{x}$ & $\mathrm{x}$ & 621 & CIG 2277 \\
\hline Astyanax sp. 2 & & $\mathrm{~N}$ & $\mathrm{NN}$ & & & & & $\mathrm{x}$ & 77 & $\begin{array}{l}\text { CIG 2259, CIG } \\
2283\end{array}$ \\
\hline Astyanax sp. 3 & & $\mathrm{~N}$ & $\mathrm{NN}$ & & & & & $\mathrm{x}$ & 154 & CIG 2284 \\
\hline Astyanax dissimilis Garavello \& Sampaio, 2010 & "lambari" & $\mathrm{NN}$ & $\mathrm{N}$ & & & $\mathrm{x}$ & & & 7 & NUP 16940 \\
\hline Astyanax serratus Garavello \& Sampaio, 2010 & "lambari" & $\mathrm{NN}$ & $\mathrm{N}$ & & & $\mathrm{x}$ & & & 11 & CIG 2381 \\
\hline Bryconamericus iheringii (Boulenger, 1887) & "lambarizinho" & $\mathrm{N}$ & $\mathrm{NN}$ & & & & & $\mathrm{x}$ & 13 & CIG 1445 \\
\hline Oligosarcus longirostris Menezes \& Géry, 1983 & "saicanga" & $\mathrm{NN}$ & $\mathrm{N}$ & $\mathrm{x}$ & & & & & 1 & NUP 11856 \\
\hline $\begin{array}{l}\text { Bryconamericus pyahu Azpelicueta, Casciotta \& } \\
\text { Almirón, } 2003\end{array}$ & "lambarizinho" & NN & $\mathrm{N}$ & & & $\mathrm{x}$ & & & 2 & NUP 12089 \\
\hline \multicolumn{11}{|l|}{ Erythrinidae } \\
\hline Hoplias aff. malabaricus (Bloch, 1794) & "traíra" & $\mathrm{N}$ & $\mathrm{N}$ & $\mathrm{x}$ & $\mathrm{x}$ & & & & 15 & CIG 2242 \\
\hline Erythrinus erythrinus (Block \& Schneider, 1801) & "jejú" & $\mathrm{N}$ & $\mathrm{NN}$ & & & & & $\mathrm{x}$ & 2 & CIG 1446 \\
\hline \multicolumn{11}{|l|}{ Trichomycteridae } \\
\hline Trichomycterus davisi (Haseman, 1911) & "candiru" & NN & $\mathrm{N}$ & $\mathrm{x}$ & & & & & 186 & $\begin{array}{l}\text { CIG 2241, CIG } \\
2245\end{array}$ \\
\hline Trichomycterus taroba Wosiacki \& Garavello, 2004 & "candiru" & $\mathrm{N}$ & $\mathrm{N}$ & $\mathrm{x}$ & & & & & 169 & NUP 3125 \\
\hline \multicolumn{11}{|l|}{ Callichthyidae } \\
\hline Corydoras sp. & "limpa-vidro" & $\mathrm{N}$ & $\mathrm{NN}$ & & & & $\mathrm{x}$ & & 151 & NUP 14261 \\
\hline \multicolumn{11}{|l|}{ Loricariidae } \\
\hline Ancistrus sp. & "cascudo-roseta" & $\mathrm{NN}$ & $\mathrm{N}$ & $\mathrm{x}$ & & & & & 30 & $\begin{array}{l}\text { NUP } 4140 \\
\text { NUP } 4489\end{array}$ \\
\hline
\end{tabular}


Continued Table 2.

\begin{tabular}{|c|c|c|c|c|c|c|c|c|c|c|}
\hline \multirow[b]{2}{*}{ Taxon } & \multirow[b]{2}{*}{ Common name } & \multicolumn{8}{|c|}{ Origin } & \multirow[b]{2}{*}{$\begin{array}{l}\text { Voucher } \\
\text { specimens }\end{array}$} \\
\hline & & $\begin{array}{c}\text { Lower } \\
\text { Paraná } \\
\text { River }\end{array}$ & $\begin{array}{l}\text { Iguaçu } \\
\text { River }\end{array}$ & S1 & S2 & S3 & S4 & S5 & Total & \\
\hline Hisonotus sp. & $\begin{array}{l}\text { "cascudinho } \\
\text { limpa-vidro" }\end{array}$ & $\mathrm{NN}$ & $\mathrm{N}$ & & & & $\mathrm{x}$ & $\mathrm{x}$ & 43 & CIG 2261 \\
\hline Hypostomus ancistroides (Ihering, 1911) & "cascudo" & $\mathrm{N}$ & NN & & & & & $\mathrm{x}$ & 2 & CIG 1448 \\
\hline Hypostomus derbyi (Haseman, 1911) & "cascudo" & $\mathrm{NN}$ & $\mathrm{N}$ & $\mathrm{x}$ & $\mathrm{x}$ & & & & 129 & NUP 4134 \\
\hline Hypostomus myersi (Gosline, 1947) & "cascudo" & $\mathrm{NN}$ & $\mathrm{N}$ & $\mathrm{x}$ & & & & & 4 & NUP 6239 \\
\hline Hypostomus sp. & "cascudo" & $\mathrm{N}$ & NN & & & & & $\mathrm{x}$ & 4 & $\begin{array}{l}\text { CIG 1420, CIG } \\
1485\end{array}$ \\
\hline \multicolumn{11}{|l|}{ Heptapteridae } \\
\hline Rhamdia voulezi Haseman, 1911 & "bagre", "jundiá" & $\mathrm{NN}$ & $\mathrm{N}$ & $\mathrm{x}$ & & $\mathrm{x}$ & & & 54 & $\begin{array}{l}\text { NUP } 11185 \text {, } \\
\text { NUP } 5678\end{array}$ \\
\hline Rhamdia aff. quelen (Quoy \& Gaimard, 1824) & "bagre", "jundiá" & $\mathrm{N}$ & NN & & & & $\mathrm{x}$ & $\mathrm{x}$ & 119 & $\begin{array}{l}\text { CIG 1475, CIG } \\
1418\end{array}$ \\
\hline \multicolumn{11}{|l|}{ GYMNOTIFORMES } \\
\hline \multicolumn{11}{|l|}{ Gymnotidae } \\
\hline Gymnotus sylvius Albert \& Fernandes-Matioli, 1999 & "morenita" & $\mathrm{NN}$ & NN & & $\mathrm{x}$ & & & $\mathrm{x}$ & 123 & CIG 1442 \\
\hline Gymnotus inaequilabiatus (Valenciennes, 1839) & "morenita" & $\mathrm{N}$ & NN & & & & & $\mathrm{x}$ & 10 & CIG 1441 \\
\hline $\begin{array}{l}\text { Gymnotus pantanal Fernandes, Albert, Daniel-Silva, } \\
\text { Lopes, Crampton \& Almeida-Toledo, } 2005\end{array}$ & "morenita" & $\mathrm{N}$ & $\mathrm{NN}$ & & & & & $\mathrm{x}$ & 9 & CIG 1451 \\
\hline \multicolumn{11}{|l|}{ SYNBRANCHIFORMES } \\
\hline \multicolumn{11}{|l|}{ Synbranchidae } \\
\hline Synbranchus cf. marmoratus Bloch, 1795 & "muçum" & $\mathrm{N}$ & $\mathrm{NN}$ & & $\mathrm{x}$ & & $\mathrm{x}$ & $\mathrm{x}$ & 16 & $\begin{array}{l}\text { CIG 1449, CIG } \\
1434\end{array}$ \\
\hline \multicolumn{11}{|l|}{ PERCIFORMES } \\
\hline \multicolumn{11}{|l|}{ Cichlidae } \\
\hline Crenicichla britskii Kullander, 1982 & "joaninha" & $\mathrm{N}$ & $\mathrm{NN}$ & & & & $\mathrm{x}$ & $\mathrm{x}$ & 21 & CIG 1483 \\
\hline Oreochromis niloticus (Linnaeus, 1758) & "tilápia" & $\mathrm{NN}$ & NN & & $\mathrm{x}$ & & & $\mathrm{x}$ & 23 & CIG 2273 \\
\hline Total number & & & & 15826 & 262 & 1056 & 1270 & 494 & 18908 & \\
\hline Richness & & & & & & & & & 40 & \\
\hline
\end{tabular}

to the Iguaçu River basin (Table 2). In terms of occurrence, 27 species have already been recorded in previous studies and other 13 are new records for the Iguaçu River basin (Astyanax sp. 3, Bryconamericus iheringii (Boulenger, 1887), Hoplias aff. Malabaricus (Bloch, 1794), Erythrinus erythrinus (Block \& Schneider, 1801), Trichomycterus sp. 3, Corydoras sp., Hypostomus ancistroides (Ihering, 1911), Hypostomus sp., Heptapterus mustelinus (Valenciennes, 1835), Rhamdia aff. quelen (Quoy \& Gaimard, 1824), Gymnotus pantanal Fernandes, Albert,
Daniel-Silva, Lopes, Crampton \& Almeida-Toledo, 2005, Poecilia reticulata Peters, 1859, and Crenicichla britskii Kullander, 1982). Of the total species sampled, 15 were endemic to the Iguaçu River basin, and observed only in streams which discharge into upstream of the Iguaçu River Falls. Still, 18 species were sampled only in streams which flow into downstream of this barrier. Only four species were common to both environments (Gymnotus sylvius Albert \& Fernandes-Matioli, 1999, Oreochromis niloticus (Linnaeus, 1758), Phalloceros harpagos, and Synbranchus cf. marmoratus). 
In the stream S1, we collected 12 species, where the most abundant in number was Phalloceros harpagos and in biomass was Astyanax bifasciatus Garavello \& Sampaio, 2010. The high numerical abundance of Phalloceros harpagos in this stream gave greater prominence to Cyprinodontiformes. Of the 12 species recorded in this stream, nine are endemic and the other three (Hoplias aff. malabaricus, Trichomycterus davisi (Haseman, 1911), and Phalloceros harpagos) are considered autochthones species (with distribution in other basins). Among the endemic species, two are considered not described (Ancistrus sp. e Characidium sp. 2) and are in the process of description (Baumgartner, D., pers. comm.).

In the stream S2, we sampled eight species, wherein Astyanax bifasciatus was the most abundant in number (45\%), and Gymnotus sylvius showed the highest biomass. This environment contained only one species endemic to the Iguaçu basin (Astyanax bifasciatus). Among the others, two are native with distribution in other basins (Hoplias aff. malabaricus and Phalloceros harpagos) and four were considered introduced (Gymnotus sylvius, Poecilia reticulata, Oreochromis niloticus, and Synbranchus cf. marmoratus).

For the stream S3, we identified 10 species, including Ancistrus mullerae Bifi, Pavanelli \& Zawadzki, 2009, a species endemic to the lower Iguaçu River, with the highest abundance, both in number and biomass ( $46 \%$ and $37 \%$, respectively). In this study, it was only registered in this stream. All species caught in this stream were considered endemic, except for Phalloceros harpagos, with wide distribution in other basins. Two species (Trichomycterus sp. 1 e Trichomycterus sp. 2) are still possibly not described (sensu Baumgartner et al. 2012).

In the stream S4, we captured 11 species: Astyanax sp. 1 presented higher abundances both number and biomass $(48 \%$ and $41 \%$, respectively). Of the species caught, five were identified only to the genus level and probably they are still not described, because they do not present the same morphological characters of other already found in the literature (Astyanax, Characidium, Corydoras, Hisonotus, and Trichomycterus). It should be noted that Corydoras sp. has been recorded exclusively in this stream (Tencatt, L. pers. comm.).

In the stream S5, we sampled 21 species, and observed high numerical abundance of the Astyanax sp. 3 and higher biomass of Gymnotus sylvius (28\% and 24\%, respectively). In this stream, as in the stream S4, seven species have possibly not been described. Six species were considered as non-native, one exotic (Oreochromis niloticus) and five allochthonous (Bryconamericus iheringii, Erythrinus erythrinus, Gymnotus inaequilabiaus (Valenciennes, 1839), Gymnotus sylvius and Gymnotus pantanal) (Graça \& Pavanelli 2007, Langeani et al. 2007, Baumgartner et al. 2012). Six species (Astyanax altiparanae Garutti \& Britski, 2000, Hypostomus albopunctatus (Regan, 1908), Gymnotus sylvius, Gymnotus inaequilabiatus, Synbranchus cf. marmoratus and Oreochromis niloticus) were previously recorded in the lower Iguaçu River (sensu Baumgartner et al. 2012). Nevertheless, none of them is considered endemic to this basin. Only two species are native to the Iguaçu River, but widely found in the Paraná River.

The NMDS summarized the composition of the fish assemblages and separated the studied streams (Figure 2). After 200 iterations, the stability criterion was met with a final stress of 0.12 (Monte Carlo test, $\mathrm{p}<0.004)$ for the two-dimensional solution. The proportion of variance represented by each axis, based on the $\mathrm{R}^{2}$ between distance in the ordination space and distance in the original space, was 0.50 for the axis 1 and 0.16 for the axis 2 . The distribution of points along the axis 1 segregated the streams upstream and downstream of the Iguaçu River Falls at the multidimensional space, suggesting that the composition of fish assemblages were highly affected by the geographical barrier (Iguaçu River Falls). We found significant differences in the composition of fish assemblages between the group of streams upstream and downstream of the falls (Hotelling's $\mathrm{T}^{2}=$ 234.36, $\mathrm{p}<0.0001)$. These results are corroborated by the Mantel test that evidenced no correlation between the similarity matrix of fish fauna composition and geographical distances among the sampled streams (Mantel $r=0.024, p=0.5$ ), demonstrating that the clusters formed in the nMDS axis 1 were not influenced by spatial autocorrelation arising from the proximity of streams.

In general, the indicator species analysis also indicated a distinction between the groups of streams. The streams upstream and downstream were characterized by different sets of indicator species (IndVal; Table 3). Six species characterized the streams upstream of the falls, except for Phalloceros harpagos, all these species were endemic to the Iguaçu basin. On the other hand, the streams flow into downstream of such biogeographical barrier were characterized by 15 indicator species, and with exception of Synbranchus cf. marmoratus, all were exclusive to these streams.

\section{Discussion}

The number of species observed in this study (40 spp.) can be considered high, especially if evaluated some issues: (i) the number of species recorded for other water bodies with similar size in the Neotropics (Bertaco 2009, Couto \& Aquino 2011, Marceniuk et al. 2011, Oyakawa \& Menezes 2011, Cetra et al. 2012, Daga et al. 2012), as well in other streams in the Paraná State (Araújo et al. 2011, Delariva \& Silva 2013, Gubiani et al. 2010); (ii) the proportion of species registered herein represents $37.7 \%$ of the total number of species recorded for the Iguaçu River basin (106 spp.), including those observed in the main channel of the river (Baumgartner et al. 2012). This high number of species is because two streams (S4 and S5) belong to the Iguaçu River basin but flow into it downstream of the Iguaçu River Falls, thus have greater connection and exchange with the fish fauna of the Paraná River basin; (iii) besides the considerable number of species that have not yet been described. Moreover, most of the records held in the Iguaçu River basin compiled in Baumgartner et al. (2012) refers to surveys in the main channel of the Iguaçu River, with the use of other fishing gears, i.e., the majority of streams in this basin have never been sampled. This condition combined with the geomorphological characteristics of the basin provides the record of species of which there is no confirmation if they are only new records or are still unknown to science.

The highest richness of the Siluriformes and Characiformes, as well as the families Characidae and Loricariidae, is a common observation in streams in the Neotropics (Lowe-McConnell 1999, Shibatta et al. 2002, Buckup et al. 2007; Langeani et al. 2007), and corroborates studies in small streams in other basins of the Paraná State (Galves et al. 2007, Cunico et al. 2009; Gubiani et al. 2010, Araújo et al. 2011, Pagotto et al. 2012, Delariva \& Silva 2013). However, for the lower Iguaçu River, were registered 11 Astyanax spp., popularly known as "lambari", of which eight species are endemic, and two possibly endemic to this basin 
Larentis, C. et al.

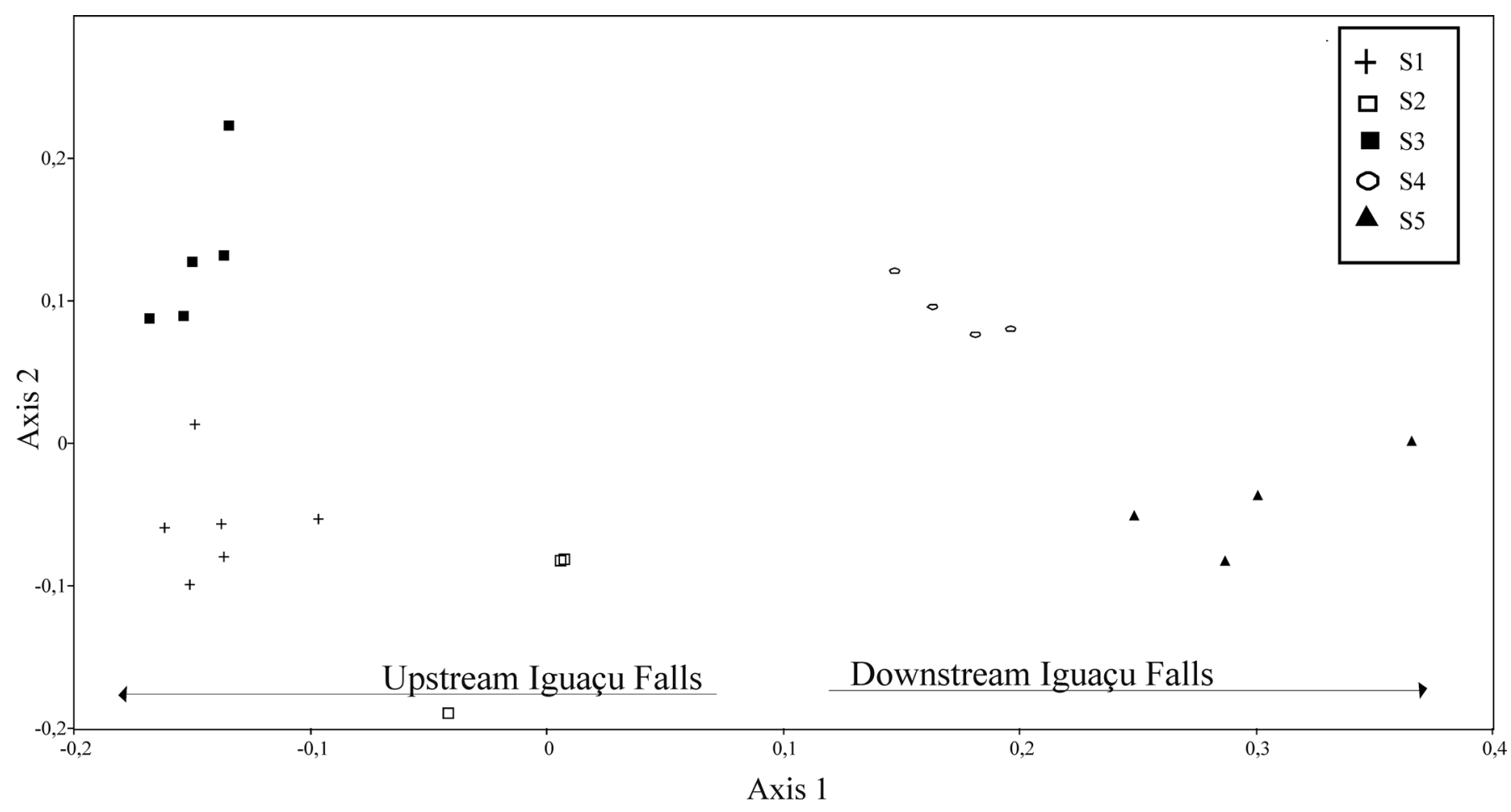

Figure 2. Non-metric multidimensional scaling (nMDS) ordination of the fish assemblages in the streams sampled in lower Iguaçu River basin, Paraná State, Brazil.

Table 3. Summary of the indicator species analysis: relative abundance, relative frequency, and indicator value for the groups of streams (up and downstream of Iguaçu River Falls) studied in lower Iguaçu River basin, Paraná State, Brazil. Only species with significant values are shown. Values in boldface indicate significant indicator values $(\mathrm{p}<0.05$, Monte Carlo test).

\begin{tabular}{lccccccc}
\hline Species & Groups & \multicolumn{2}{l}{ Relative abundance } & Relative frequency & Indicators values \\
\hline Astyanax bifasciatus & 1 & 100 & 0 & 94 & 0 & $\mathbf{9 4}$ & 0 \\
Trichomycterus davisi & 1 & 100 & 0 & 50 & 0 & $\mathbf{5 0}$ & 0 \\
Trichomycterus taroba & 1 & 100 & 0 & 50 & 0 & $\mathbf{5 0}$ & 0 \\
Hypostomus derbyi & 1 & 100 & 0 & 56 & 0 & $\mathbf{5 6}$ & 0 \\
Rhamdia voulezi & 1 & 100 & 0 & 50 & 0 & $\mathbf{5 0}$ & 0 \\
Phalloceros harpagos & 1 & 97 & 3 & 94 & 50 & $\mathbf{9 1}$ & 2 \\
Characidium sp. 1 & 2 & 0 & 100 & 0 & 63 & 0 & $\mathbf{6 3}$ \\
Astyanax sp. 1 & 2 & 0 & 100 & 0 & 75 & 0 & $\mathbf{7 5}$ \\
Astyanax sp. 2 & 2 & 0 & 100 & 0 & 50 & 0 & $\mathbf{5 0}$ \\
Astyanax sp. 3 & 2 & 0 & 100 & 0 & 50 & 0 & $\mathbf{5 0}$ \\
Astyanax lacustris & 2 & 0 & 100 & 0 & 50 & 0 & $\mathbf{5 0}$ \\
Briconamericus iheringii & 2 & 0 & 100 & 0 & 50 & 0 & $\mathbf{5 0}$ \\
Trichomycterus sp. 3 & 2 & 0 & 100 & 0 & 63 & 0 & $\mathbf{6 3}$ \\
Corydoras sp. & 2 & 0 & 100 & 0 & 50 & 0 & $\mathbf{5 0}$ \\
Hisonotus sp. & 2 & 0 & 100 & 0 & 63 & 0 & $\mathbf{6 3}$ \\
Hypostomus albopunctatus & 2 & 0 & 100 & 0 & 63 & 0 & $\mathbf{6 3}$ \\
Heptapterus mustelinus & 2 & 0 & 100 & 0 & 50 & 0 & $\mathbf{5 0}$ \\
Rhamdia aff. quelen & 2 & 0 & 100 & 0 & 100 & 0 & $\mathbf{1 0 0}$ \\
Gymnotus pantanal & 2 & 0 & 100 & 0 & 38 & 0 & $\mathbf{3 8}$ \\
Synbranchus cf. marmoratus & 2 & 7 & 93 & 13 & 75 & 1 & $\mathbf{7 0}$ \\
Crenicichla britskii & 2 & 0 & 100 & 0 & 50 & 0 & $\mathbf{5 0}$ \\
\hline
\end{tabular}


(Baumgartner et al. 2012). In our study, we recorded four Astyanax spp., three possibly endemic. Other three species are possibly new, totaling seven Astyanax spp., which explains the high contribution of Characidae in our study.

Most of the species verified in this study is considered small size, which is expected to small water bodies (Bifi et al. 2006, Araújo et al. 2011, Cionek et al. 2012). According to Castro (1999), this pattern is shared by the fauna of South American streams and is mainly related to historical and evolutionary factors. It is noteworthy that a high number of small-sized species is even more evident in the fish fauna of the Iguaçu basin, even considering the species occurring in the main channel of the river. According to Garavello et al. (1997), the scarcity of rheophilic or large migratory species in this basin can be attributed to the formation of the Iguaçu River Falls, with an abrupt elevation, which interrupted the faunal exchange with the Paraná River basin.

In general, a high degree of endemism is reported to streams (Castro 1999, Casatti 2010). However, it was more evident in the fauna of the Iguaçu River, with about $70 \%$ of endemic fish (Baumgartner et al. 2012). The formation of the falls isolated the upper from the lower reach of the Iguaçu River basin (Parolin et al. 2010), providing different scenarios for the evolution of species. This resulted in species with unique characteristics in the upper section. The indicator species for the two groups of streams corroborate this hypothesis, especially, because all indicator species of the group of streams upstream of the falls are endemic to the Iguaçu River. On the other hand, downstream of the falls was observed a higher number of indicator species, wherein, except Synbranchus cf. marmoratus, all were common to the fauna of the Paraná River. The occurrence of the distinct species in downstream indicates that the streams S4 and S5 remained connected below of the falls. In this way, although these streams belong to the Iguaçu River basin, its fish fauna evolved following similar patterns those observed for the Paraná River basin. This result strongly supports the hypothesis of distinction between the stream fish fauna upstream and downstream of the Iguaçu River Falls. Accordingly, corroborates with the already postulated effects of biogeographical barriers in the differentiation of the fish fauna and especially in endemism (Olden et al. 2010, TorrenteVilara et al. 2011, Dias et al. 2012, Vitule et al. 2012).

Despite these general patterns, the fish fauna of each stream can be considered exclusive to their microbasins, as demonstrated by the high number of species not yet described. The presence of species common to both environments, such as Gymnotus sylvius, Oreochromis niloticus, Phalloceros harpagos, and Synbranchus cf. marmoratus, should be considered with reservation, because except for Phalloceros harpagos, for the other species there is the possibility of escapes or introductions via their use as bait (Graça \& Pavanelli 2007, Baumgartner et al. 2012).

Regarding the differences in fish composition between streams upstream of the barrier (Iguaçu River Falls), it may be associated with conditions of preservation of streams sampled. For example, we have a high numerical abundance of Phalloceros harpagos in one of the streams (S1), where, besides the activity of livestock, human activities, such as the construction of a bridge, altered the normal course of the river, favoring the proliferation of less demanding species (Bifi et al. 2006, Lange et al. 2014). On the other hand, the presence of Poecilia reticulata in the stream $\mathrm{S} 2$, is possibly because to its location, near the urban center of municipality of Cascavel, since this species could be released or escape from aquarium. Tolerant non-native species in altered streams were recorded in several studies in streams of other basins in the Paraná State (Cunico et al. 2009, Araújo et al. 2011, Pagotto et al. 2012). The presence of non-native species is considered a major factor in the reduction of the native community (Jackson 2002, Di Prinzio et al. 2009, Eros et al. 2014, Zeni \& Casatti 2014). In this study, the occurrences of Gymnotus and Synbranchus species can be attributed to the use of species of such genera as live bait (Graça \& Pavanelli 2007, Baumgartner et al. 2012). These results confirm that huge changes in the use and occupation of land can cause changes in native fish assemblages in inland freshwater ecosystems.

Furthermore, despite having completely different fish fauna composition, the streams S3 and S4 showed a high number of native species (to the Iguaçu River and Paraná River, respectively). In addition, these streams are located near the 'Parque Nacional do Iguaçu', which suggests a higher degree of preservation. This fact shows that preserved environments offers better conditions for the permanence of native species (Lyons et al. 1995, Saunders et al. 2002, Casatti et al. 2012), which are more sensitive to changes, ensuring the preservation of endemism of this fish fauna.

The results summarized in this study show strongly the significant effect of the Iguaçu River Falls as a natural biogeographic barrier for speciation of fish species and endemism in streams of the Iguaçu River basin, leading to the development of distinct faunas in water bodies located upstream and downstream of such waterfalls. Although others studies had shown that geologic processes provide the capture of headwaters by adjacent basins (Ribeiro 2006; Dagosta et al. 2014), this seems not to be the case of this study. So, the main insight of our study is related to fact that differentiation has occurred in species composition between streams up and downstream and that these follow a similar pattern for the registered to the fish fauna of the principal channel. Thereby, it is stressed the importance of further surveys in headwaters streams, especially in the Iguaçu River to confirm and consolidate this findings. Peculiarities of this basin as the presence of geographical barriers (falls) with different levels of isolation, should provide different scenarios for speciation of the fish fauna.

The high number of endemic species not yet described deserves the attention of researchers and experts, so that they can be recognized by science and thus conserved, in order to maintain the biodiversity of freshwater ecosystems. In this context, we confirm the claim of Nogueira et al. (2010) who reported that a comprehensive strategy for the conservation of freshwater fish species in Brazil needs to address studies for restricted-range endemic species. Also, the presence of non-native species was more closely associated with streams under the influence of adjacent urban areas. These findings, along with urban sprawl in the lower Iguaçu River region, reinforce the imminent need for knowledge of this fauna, considering that the extinction of species in this region means the irreparable loss of them. In addition, considering that the basic unit of management is the basin, we suggested that it should be considered geographical spaces delimited by natural or artificial barriers as units separated in the basin when developing and implementing monitoring programs, impact studies and conservation plans. 


\section{Acknowledgments}

We thank the researches of GERPEL for helping in the sampling and the Universidade Estadual do Oeste do Paraná for providing logistical support for sampling. We also thank to researchers of the Ichthyology Collection of Núcleo de Pesquisas em Limnologia, Ictiologia e Aquicultura, of the Universidade Estadual de Maringá, in special to Luiz Tencatt, for helping to identify the Corydoras species.

\section{References}

ARAÚJO, M.I., DELARIVA, R.L., BONATO, K.O. \& SILVA, J.C. 2011. Fishes in first order stream in Ivaí River drainage basin, upper Paraná River Basin, Paraná state, Brazil. Check List 7(6): 774-777.

BAUMGARTNER, D., BAUMGARTNER, G., PAVANELLI, C.S., SILVA, P.R.L., FRANA, V.A., OLIVEIRA, L.C. \& MICHELON, M.R. 2006. Fish, Salto Osório Reservoir, rio Iguaçu basin, Paraná State, Brazil. Check List 2(1): $1-4$

BAUMGARTNER, G., PAVANELLI, C.S., BAUMGARTNER, D., BIFI, A.G., DEBONA, T. \& FRANA, V.A. 2012. Peixes do baixo Rio Iguaçu. Eduem, Maringá.

BERTACO, V.A. 2009. Freshwater Fishes, Ilha de Santa Catarina, southern coastal drainage of the state of Santa Catarina, Brazil. Check List 5(4): 898-902.

BIFI, A.G., BAUMGARTNER, D., BAUMGARTNER, G., FRANA, V.A. \& DEBONA, T. 2006. Composição específica e abundância da ictiofauna do rio dos Padres, bacia do rio Iguaçu, Brasil. Acta Scient. Biol. Sci. 28(3): 203-211.

BUCKUP, P.A., MENEZES, N.A. \& GHAZZI, M.S. 2007. Catálogo das espécies de peixes de água doce do Brasil. Museu Nacional, Rio de Janeiro.

CASATTI, L. 2010. Alterações no Código Florestal Brasileiro: impactos potenciais sobre a ictiofauna. Biota Neotrop. 10(4): 30-34 http://www. biotaneotropica.org.br/v10n4/en/abstract?article+bn00310042010 (last access at 17/11/2015)

CASATTI, L., TERESA, F.B., GONÇALVES-SOUZA, T., BESSA, E., MANZOTTI, A.R., GONÇALVES, C.S. \& ZENI, J.O. 2012. From forests to cattail: how does the riparian zone influence stream fish? Neotrop. Ichthyol. 10: 205-214.

CASTRO, R.M.C. 1999. Evolução da ictiofauna de riachos Sul-Americanos: Padrões gerais e possíveis processos casuais. In Ecologia de Peixes de Riachos: Estado Atual e Perspectivas (E.P. Caramaschi, R. Mazzoni, C.R.S.F. Bizerril \& P.R. Peres-Neto, eds.). Oecol. Bras., Rio de Janeiro, p.139-155.

CETRA, M., BARRELLA, W., LANGEANI, F., MARTINS, A.G., MELLO, B.J. \& ALMEIDA, R.S. 2012. Fish fauna of headwater streams that cross the Atlantic Forest of south São Paulo state. Check List 8(3): 421-425.

CIONEK, V.M., SACRAMENTO, P.A., ZANATTA, N., OTA, R.P., CORBETTA, D.F. \& BENEDITO, E. 2012. Fishes from first order streams of lower Paranapanema and Ivaí rivers, upper Paraná River basin, Paraná, Brazil. Check List 8(6): 1158-1162.

COUTO, T.B.A \& AQUINO, P.P.U. 2011. Structure and integrity of fish assemblages in streams associated to conservation units in Central Brazil. Neotrop. ichthyol. 9(2): 445-454.

CRACRAFT, J. 1982. A nonequilibrium theory for the rate-control of speciation and extinction and the origin of macroevolutionary patterns. Syst. Biol. 31: 348-365.

CUNICO, A.M., AGOSTINHO, A.A. \& LATINI, J.D. 2006. Influência da urbanização sobre as assembleias de peixes em três córregos de Maringá, Paraná. Rev. Bras. Zool. 23(4): 1101-1110.

CUNICO, A.M., GRAÇA, W.J., AGOSTINHO, A.A., DOMINGUES, V.M. \& LATINI, J.D. 2009. Fish, Maringá Urban Streams, Pirapó river drainage, upper Paraná river basin, Paraná State, Brazil. Check List 5(2): 273-280.

DAGA, V.S., GUBIANI, E.A., CUNICO, A.M. \& BAUMGARTNER, G. 2012. Effects of abiotic variables on the distribution of fish assemblages in streams with different anthropogenic activities in southern Brazil. Neotrop. ichthyol. 10(3): 643-652.
DAGOSTA, F.C.P., MARINHO, M.M.F. \& CAMELIER, P. 2014. A new species of Hyphessobrycon Durbin (Characiformes: Characidae) from the middle rio São Francisco and upper and middle rio Tocantins basins, Brazil, with comments on its biogeographic history. Neotrop. ichthyol. 12(2): 365-375.

DELARIVA, R.L. \& SILVA, J.C. 2013. Fish fauna of headwater streams of Perobas Biological Reserve, a conservation unit in the Atlantic Forest of the Northwestern Paraná State, Brazil. Check List 9(3): 549-554.

DI PRINZIO, C.Y., CASAUX, R.J. \& MISERENDINO, M.L. 2009. Effects of land use on fish assemblages in Patagonian low order streams. Int. J. Limnol. 45(04): 267-277.

DIAS, M.S., CORNU, J.F., OBERDORFF, T., LASSO, C.A. \& TEDESCO, P.A. 2012. Natural fragmentation in river networks as a driver of speciation for freshwater fishes. Ecography 35: 001-007.

DUFRÊNE, M. \& LEGENDRE, P. 1997. Species assemblages and Indicator Species: the need for a flexible symmetrical approach. Ecol. monogr. 67: 345-366.

EROS, T., SÁLY, P., TAKÁCS, P., HIGGINS, C.L., BÍRÓ, P. \& SCHMERA, D. 2014. Quantifying temporal variability in the metacommunity structure of stream fishes: the influence of non-native species and environmental drivers. Hydrobiologia 722: 31-43.

GALVES, W., JEREP, F.C. \& SHIBATTA, O.A. 2007. Estudo da condição ambiental pelo levantamento da fauna de três riachos na região do Parque Estadual Mata dos Godoy (PEMG), Londrina, PR, Brasil. PanamJAS 2(1): 55-65.

GARAVELLO, J.C., BRITSKI, H.A. \& ZAWADZKI, C.H. 2012. The cascudos of the genus Hypostomus Lacépède (Osteichthyes: Loricariidae) from the rio Iguaçu basin. Neotrop. ichthyol. 10(2): 263-283.

GARAVELLO, J.C. \& SAMPAIO, F.A.A. 2010. Five new species of genus Astyanax Baird \& Girard, 1854 from Rio Iguaçu, Paraná, Brazil (Ostariophysi, Characiformes, Characidae). Braz. J. Biol. 70(3): 847-865.

GARAVELLO, J.C., PAVANELLI, C.S., SUZUKI, H.I. 1997. Caracterização da ictiofauna do rio Iguaçu. In Reservatório de Segredo, bases ecológicas para o manejo (A.A. Agostinho \& L.C. Gomes, eds.). Eduem, Maringá, p. 61-84.

GRAÇA, W.J. \& PAVANELLI, C.S. 2007. Peixes da Planície de inundação do Alto rio Paraná e áreas adjacentes. 1 ed. Eduem, Maringá.

GUBIANI, E.A., DAGA, V.S., FRANA, V.A. \& GRAÇA, W.J. 2010. Fish, Toledo urban streams, São Francisco Verdadeiro River drainage, upper Paraná River basin, state of Paraná, Brazil. Check List 6(1): 45-48.

HAMMER, D.A., HARPER, T. \& RYAN, P.D. 2001. PAST: Paleotological Statistics Software package for education and data analysis. Paleontol. Electron. 4: 1-9.

JACKSON, D.A. 2002. Ecological effects of Micropterus introductions: the dark side of black bass. In: Black Bass: Ecology, Conservation and Management (D.P. Phillip \& M.S. Ridgway, eds.). American Fisheries Society Symposium 31: 221-232.

LANGE, K., TOWNSEND, C.R., GABRIELSSON, R., CHANUT, P.C.M. \& MATTHAEI, C.D. 2014. Responses of stream fish populations to farming intensity and water abstraction in an agricultural catchment. Freshw. biol. 59(2): 286-299.

LANGEANI, F., CASTRO, R.M.C., OYAKAWA, O.T., SHIBATTA, O.A., PAVANELLI, C.S. \& CASATTI, L. 2007. Diversidade da ictiofauna do Alto Rio Paraná: composição atual e perspectivas futuras. Biota Neotrop. 7(3): 1-17 http://www.biotaneotropica.org.br/ v7n3/pt/abstract?article+bn03407032007 (last access at 14/01/2016)

LOWE-MCCONNELL, R.H. 1999. Estudos Ecológicos de Comunidades de peixes tropicais. Coleção Base, Edusp, São Paulo.

LYONS, J., NAVARRO-PÉREZ, S., COCHRAN, P.A., SANTANA, C. \& GUZMÁN-ARROYO, M. 1995. Index of biotic integrity based on fish assemblages for the conservation of streams and rivers in west-central México. Conserv. biol. 9(3): 569-584

MARCENIUK, A.P., HILSDORF, A.W.S. \& LANGEANI, F. 2011. The ichthyofauna from the headwaters of the rio Tietê, São Paulo, Brazil. Biota Neotrop. 11(3) http://www.biotaneotropica.org.br/v11n3/en/abstract?inven tory+bn00311032011 (last access at 05/09/2015) 
MCCUNE, B. \& GRACE, J.B. 2002. Analysis of ecological communities. MjM Software Design, Gleneden Beach, Oregon, USA.

MCCUNE, B. \& MEFFORD, M.J. 2011. PC-ORD. Multivariate analysis of ecological data.Version 6.0. MjM Software, Gleneden Beach, Oregon, USA.

MEEUWIG, M.H., GUY, C.S., KALINOWSKI, S.T. \& FREDENBERG, W.A 2010. Landscape influences on genetic differentiation among bull trout populations in a stream-lake network. Mol. ecol. 19: 3620-3633.

MIRANDE, J.M. 2009. Weighted parsimony phylogeny of the family Characidae (Teleostei: Characiformes). Cladistics 25(6): 574-613.

NELSON, J.S. 2006. Fishes of the world. John Wiley \& Sons, New York.

NOGUEIRA, C., BUCKUP, P.A., MENEZES, N.A., OYAKAWA, O.T., KASECKER, T.P., RAMOS NETO, M.B. \& SILVA, J.M.C. 2010. Restricted-range fishes and the conservation of Brazilian freshwaters. PLoS One 5(6): e11390.

OLDEN, D.J., KENNARD, M.J., LEPRIEUR, F., TEDESCO, P.A., WINEMILLER, K.O. \& GARCÍA-BERTHOU, E. 2010. Conservation biogeography of freshwater fishes: recent progress and future challenges. Divers. distrib. 16(3): 496-513.

OYAKAWA, O.T. \& MENEZES, N.A. 2011. Checklist of fresh water fishes from São Paulo State, Brazil. Biota Neotrop. 11, 19-32. http://www. biotaneotropica.org.br/v11n1a/en/abstract?inventory+bn0021101a2011 (last access at 17/03/2015)

PAGOTTO, J.P.A., VERÍSSIMO, S., GOULART, E. \& MISE. F.T. 2012. Fishes (Osteichthyes: Actinopterygii) from the Pirapó River drainage, upper Paraná River basin, Paraná state, Brazil. Check List 8(3): 463-468.

PAROLIN, M., RIBEIRO, C.V. \& LEANDRINI, J.A. 2010. Abordagem ambiental interdisciplinar em bacias hidrográficas no Estado do Paraná. Editora da Fecilcam, Campo Mourão.

PAVANELLI, C.S. \& CARAMASCHI, E.P. 2003. Temporal and spatial distribution of the ichthyofauna in two streams of the upper rio Paraná basin. Braz. Arch. Biol. Technol. 46: 271-280.

RAHEL, F.J. 2007. Biogeographic barriers, connectivity and homogenization of freshwater faunas: it's a small world after all. Freshw. biol. 52: 696-710.

REIS, R.E., KULLANDER, S.O. \& FERRARIS JR., C.J. 2003. Check list of freshwater fishes of South and Central America. Edipucrs, Porto Alegre.

RIBEIRO, A.C. 2006. Tectonic history and the biogeography of the freshwater fishes from the coastal drainages of eastern Brazil: an example of faunal evolution associated with a divergent continental margin. Neotrop. ichthyol. 4(2): 225-246.
SAUNDERS, D.L., MEEUWIG, J.J. \& VINCENT, A.C.J. 2002. Freshwater protected areas: strategies for conservation. Conserv. biol. 16(1): 30-41.

SEMA, Secretaria de Estado do Meio Ambiente e Recursos Hídricos. 2013. Bacias Hidrográficas do Paraná. Série Histórica, 2 ed, Curitiba.

SHIBATTA, O.A., ORSI, M.L., BENNEMANN, S.T. \& SILVA-SOUZA, A.T. 2002. Diversidade e distribuição de peixes na bacia do rio Tibagi. In A bacia do rio Tibagi (M.E. Medri, E. Bianchini, O.A. Shibatta \& J.A. Pimenta, eds.). Universidade Estadual de Londrina, Londrina. p. 403-423.

SUZUKI, H.I., PAVANELLI, C.S., FUGI, R., BINI, L.M. \& AGOSTINHO, A.A. 1997. Ictiofauna de quatro tributários do reservatório de Segredo. In: Reservatório de segredo: bases ecológicas para o manejo (A.A. Agostinho \& L.C. Gomes, eds.). Eduem, Maringá. p. 259-273.

TORRENTE-VILLARA, G., ZUANON, J., LEPRIEUR, F., OBERDORFF, T. \& TEDESCO, P.A. 2011. Effects of natural rapids and waterfalls on fish assemblage structure in the Madeira River (Amazon Basin). Ecol. freshw. fish 20: 588-597.

VICARI, M.R., PAZZA, R., ARTONI, R.F., MARGARIDO, V.P. \& BERTOLLO, L.A.C. 2006. Cytogenetics and Biogeography: considerations about the Natural Origin of Hoplias malabaricus (Characiformes, Erythrinidae) on the Iguaçu River. Braz. Arch. Biol. Technol. 49(2): 297-303.

VITULE, J.R.S. \& ABILHOA, V.A. 2003. Composição da ictiofauna na bacia hidrográfica do rio Piraquara, alto rio Iguaçu, Região Metropolitana de Curitiba, Paraná, Brasil. Estud. Biol. 25(52): 43-49.

VITULE, J.R.S., FREIRE, C.A., VAZQUEZ, D.P., NUÑEZ, M.A. \& SIMBERLOFF, D. 2012. Revisiting the Potential Conservation Value of Non-Native Species. Conserv. biol. 26(6): 1153-1155.

ZAWADZKI, D.H., RENESTRO, E. \& BINI, L.M. 1999. Genetic and morphometric analysis of three species of the genus Hypostomus Lacépède, 1803 (Osteichthyes: Loricariidae) from the Rio Iguaçu basin (Brazil). Rev. suisse zool. 106(1): 91-105.

ZENI, J.O. \& CASATTI, L. 2014. The influence of habitat homogenization on the trophic structure of fish fauna in tropical streams. Hydrobiologia 726: $259-270$. 